\title{
Gambaran rasa takut anak SD GMIM IV Tomohon pada perawatan penambalan gigi
}

\author{
Joyce Kandou ${ }^{1}$, Paulina Gunawan ${ }^{2}$, Jade Lolong ${ }^{3}$ \\ ${ }^{1}$ Bagian Psikologi RSUP Prof. Dr. R.D. Kandou Manado \\ ${ }^{2}$ Program Studi Kedokteran Gigi \\ ${ }^{3}$ Mahasiswa Program Studi Kedokteran Gigi \\ Fakultas Kedokteran Universitas Sam Ratulangi
}

\begin{abstract}
ABSTRAK
Rasa takut terhadap perawatan gigi dan mulut khususnya pada perawatan penambalan gigi merupakan hambatan terbesar bagi dokter gigi dalam melakukan perawatan yang optimal. Tindakan preventif dan restoratif seperti penambalan gigi penting agar gigi tetap berfungsi normal serta menjaga ruang bagi pertumbuhan gigi permanen. Di seluruh dunia, prevalensi rasa takut pada perawatan gigi dan mulut mencapai $6-15 \%$ dari seluruh populasi, namun cukup bervariasi di berbagai bagian dunia dan pada populasi sampel yang berbeda. Tujuan dari penelitian ini adalah untuk mendapatkan gambaran mengenai rasa takut sera prosedur dental yang paling menakutkan pada tindakan penambalan gigi bagi pasien anak. Metode penelitian yang digunakan adalah penelitian deskriptif. Penelitian ini dilakukan dengan mewawancarai secara langsung 60 pasien anak usia 10-11 tahun di SD GMIM IV Tomohon yang sudah pernah menjalani perawatan penambalan gigi. Sampel diambil dengan menggunakan simple random sampling. Rasa takut anak usia 10-11 tahun di SD GMIM IV Tomohon pada perawatan penambalan gigi secara umum masuk dalam kategori rendah dengan persentase $65 \%$. Prosedur dental yang paling menakutkan pada anak usia 10-11 tahun di SD GMIM IV Tomohon adalah saat mendengar bunyi mesin bur dokter gigi dan saat dokter gigi mengebur atau bur bersentuhan dengan gigi.
\end{abstract}

Kata Kunci : rasa takut, perawatan penambalan gigi, indeks pengukuran rasa takut pada anak.

\section{ABSTRACT}

Dental fear particularly in dental fillings treatment is one of the biggest obstacle for dentist in performing an optimal treatments. Preventive and restorative treatments such as dental fillings is important for maintain normal function of primary teeth and space for the permanent dentition. The prevalence of dental fear is up to 6-15\% worldwide, however it vary in some parts of the world and in different population sample. The purpose of this research is to obtain an overview of fear and the most frightening procedures of dental feelings treatment for pediatric patients. The method used in this research is descriptive study. This research was performed by interviewing 60 child dental patients aged 10-11 years old from GMIM IV Tomohon elementary school who has received dental fillings treatment. Samples were taken using simple random sampling method. Percentage of dental fillings treatment fear in children aged 10-11 years old in GMIM IV Tomohon elementary school is 65\% categorized in low-level. The most frightening procedures for pediatric patients are when he/she heard the noise of dentist drilling machine and when the drill contact with the surface of teeth.

Keywords : fear, dental fillings treatment, children fear survey scedule - dental subscale.

\section{PENDAHULUAN}

Kecemasan atau ketakutan terhadap perawatan dental sering dijadikan alasan utama untuk tidak melakukan perawatan gigi. ${ }^{1}$ Dalam upaya peningkatan derajat kesehatan gigi dan mulut pada anakanak, rasa takut merupakan hambatan bagi dokter gigi yang dapat menyebabkan perilaku negatif anak ketika menjalani prosedur perawatan. ${ }^{1,2}$ Menurut penelitian yang dilakukan oleh Cormac dan Jenkins yang diukur dengan tiga jenis kuesioner yang berbeda pada populasi yang sama menunjukkan bahwa prevalensi rasa takut terhadap perawatan gigi berkisar $8,2-24 \%{ }^{3}$ 
Sangatlah penting bagi seorang dokter gigi untuk memahami perasaan takut anak pada setiap tindakan perawatan gigi dan mulut karena dapat membuat pasien khususnya pasien anak menunda atau bahkan tidak mau melakukan perawatan serta bersikap nonkooperatif pada saat duduk di kursi gigi. ${ }^{1,4}$ Perawatan gigi dan mulut pada anak pada umumnya dimulai saat usia sekolah dasar, dimana banyak diantaranya menghadapi pengalaman pertama yang kurang menyenangkan sehingga dapat menjadi suatu kecemasan yang berkembang menjadi ketakutan yang kemudian menetap hingga dewasa. ${ }^{5,6}$ Survei yang dilakukan Locker dan Lindell pada tahun 2008 terhadap 1420 orang, sebanyak 16,4\% memiliki rasa takut pada perawatan gigi dan dari hasil tersebut sebanyak 50,9\% muncul pada masa kanak - kanak, 22\% pada dewasa muda, dan $27,1 \%$ pada orang dewasa. ${ }^{4}$

Sering dijumpai kecendurangan anak yang takut pergi ke dokter gigi untuk melakukan perawatan gigi dan mulut, seperti tindakan penambalan gigi. ${ }^{1,7}$ Prosedur dalam tindakan penambalan seperti pada saat dokter gigi mengebur seringkali membuat pasien anak menjadi sangat takut bahkan menolak untuk dirawat. ${ }^{2,3}$ Tindakan preventif dan restoratif seperti penambalan gigi berguna untuk menjaga gigi agar tetap berfungsi normal dan sebagai penuntun arah serta menjaga ruang bagi pertumbuhan gigi permanen. ${ }^{5}$ Sampai saat ini, diperkirakan jumlah populasi dunia yang menderita high dental fear sebesar 6-15\%. Menurut survei yang dilakukan Todd dan Walker terhadap 6000 orang, 58\% responden menyatakan alasan mereka menunda perawatan gigi dan mulut karena takut terhadap dokter gigi. ${ }^{3}$

Tugas dari dokter gigi adalah mengurangi rasa takut terhadap perawatan gigi dan mulut pasien anak sampai pada tingkat normal sehingga dapat tercipta perilaku positif dalam menerima setiap perawatan. 5 Penting bagi dokter gigi untuk memahami sikap, sifat, dan perilaku pasien anakanak. $^{1,7,8}$

\section{BAHAN DAN METODE}

Jenis penelitian yang digunakan adalah survey deskriptif. Penelitian dilaksanakan pada tanggal 16-17 Juli 2013. Penelitian ini sudah dilaksanakan di SD GMIM IV Tomohon. Populasi target pada penelitian adalah seluruh siswa di SD GMIM IV Tomohon, sedangkanpopulasi terjangkau adalah seluruh siswa kelas V dan VI di SD GMIM IV Tomohon yang berjumlah 148 siswa.

Kriteria inklusi yaitu bersedia menjadi subjek penelitian, sudah pernah menjalani perawatan penambalan gigi di praktek dokter gigi / Rumah Sakit / Puskesmas, anak-anak yang duduk di kelas $\mathrm{V}$ dan VI yang berusia 10-11 tahun, sedangkan yang menjadi kriteria eksklusi yaitu belum pernah berkunjung ke dokter gigi. Metode pengambilan sampel yang digunakan adalah simple random sampling. Ukuran sampel ditentukan dengan menggunakan Rumus Slovin, yaitu :

$$
\begin{aligned}
& \mathrm{n}=\frac{\mathrm{N}}{1+\mathrm{N} \cdot \mathrm{d}^{2}}=\frac{148}{1+148 \cdot(0,1)^{2}} \\
& \mathrm{n}=59,68-60
\end{aligned}
$$

Keterangan :

$\mathrm{n}=$ Ukuran sampel

$\mathrm{N}=$ Ukuran populasi

$\mathrm{d}=$ Derajat ketepatan yang diinginkan adalah $0,1(10 \%)$

Alat ukur rasa takut yang digunakan adalah kuesioner Children Fear Survey Scedule-Dental Subscale (CFSS-DS) yang telah dimodikasi dan terdiri atas 9 pernyataan yang berkaitan dengan 
lingkungan perawatan gigi dan mulut serta beberapa prosedur umum penambalan gigi. Skor untuk kategori tidak takut 1, agak takut 2, takut 3, sangat takut 4, dan amat sangat takut 5. Jumlah skor $\mathrm{n} \leq 15$ dikategorikan memiliki tingkat rasa takut pada tindakan penambalan gigi yang rendah, $15<\mathrm{n}$ $\leq 30$ memiliki tingkat rasa takut pada tindakan penambalan gigi yang sedang, dan $30<\mathrm{n} \leq 45$ memiliki tingkat rasa takut pada tindakan penambalan gigi yang tinggi, dengan $\mathrm{n}$ adalah jumlah skor. Pada setiap kategori ditambahkan gambar ekpresi wajah sebagai berikut :

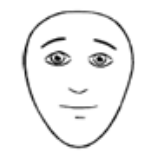

Tidak takut

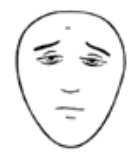

Agak takut

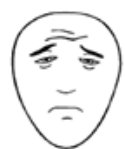

Takut

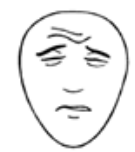

Sangat takut

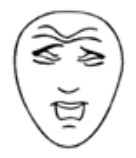

Amat sangat

Pengumpulan data rasa takut dengan mewawancarai anak secara langsung berdasarkan kuesioner CFSS-DS yang telah dimodifikasi. Editing dilakukan pada semua kuesioner untuk memeriksa kembali jawabannya. Setelah semua data diperoleh, data dipindahkan dan dikategorikan sesuai dengan variabel penelitian. Analisis data dilakukan dengan cara menghitung tingkat rasa takut anak pada perawatan penambalan gigi berdasarkan skor CFSS-DS dan menghitung jumlah skor tertinggi pada kuesioner CFSS-DS yang menyatakan prosedur penambalan gigi yang paling menakutkan pada pasien anak.

\section{HASIL DAN PEMBAHASAN}

\section{A. Hasil Penelitian}

Tabel 1. Tingkat rasa takut anak pada perawatan penambalan gigi.

\begin{tabular}{|c|c|c|c|c|c|c|}
\hline \multirow[b]{2}{*}{ No. } & \multirow[b]{2}{*}{ Sumber Rasa Takut } & \multicolumn{5}{|c|}{ Kategori } \\
\hline & & $\begin{array}{l}\text { Tidak } \\
\text { Takut }\end{array}$ & $\begin{array}{l}\text { Agak } \\
\text { Takut }\end{array}$ & Takut & $\begin{array}{l}\text { Sangat } \\
\text { Takut }\end{array}$ & $\begin{array}{c}\text { Amat } \\
\text { Sangat } \\
\text { Takut }\end{array}$ \\
\hline 1. & Dokter gigi & 49 & 11 & 0 & 0 & 0 \\
\hline 2. & Orang berseragam putih & 60 & 0 & 0 & 0 & 0 \\
\hline 3. & Suasana ruangan praktek dokter gigi & 51 & 8 & 1 & 0 & 0 \\
\hline 4. & Saat disuruh duduk di kursi gigi & 39 & 21 & 0 & 0 & 0 \\
\hline 5. & Peralatan dokter gigi & 31 & 16 & 10 & 2 & 1 \\
\hline 6. & $\begin{array}{l}\text { Saat dokter gigi memasukkan instrumen } \\
\text { dalam mulut/memeriksa mulut }\end{array}$ & 37 & 18 & 4 & 1 & 0 \\
\hline 7. & $\begin{array}{l}\text { Saat mendengar bunyi mesin bur dokter } \\
\text { gigi }\end{array}$ & 18 & 27 & 12 & 1 & 2 \\
\hline 8. & $\begin{array}{l}\text { Saat dokter gigi mengebur/bur } \\
\text { bersentuhan dengan gigi }\end{array}$ & 12 & 28 & 15 & 3 & 2 \\
\hline 9. & $\begin{array}{l}\text { Saat dokter gigi menumpat/menambal } \\
\text { gigi }\end{array}$ & 24 & 28 & 6 & 1 & 1 \\
\hline
\end{tabular}

Tabel 1 menunjukkan tingkat rasa takut anak terhadap 9 variabel. Jumlah terbesar dari 9 variabel untuk tingkat rasa takut pada perawatan penambalan gigi dengan kategori amat sangat takut dengan jumlah 2 orang terdapat pada variabel 7 (saat mendengar bunyi mesin bur dokter gigi) dan variabel 8 (saat bur bersentuhan dengan gigi), kategori sangat takut dengan jumlah 3 orang pada variabel 8 (saat bur bersentuhan dengan gigi), kategori takut dengan jumlah 15 orang pada variabel 8 (saat bur bersentuhan dengan gigi), kategori agak takut dengan jumlah 28 orang pada variabel 8 
(saat bur bersentuhan dengan gigi) dan variabel 9 (saat dokter gigi menumpat/menambal gigi) sedangkan jumlah terbesar pada kategori tidak takut yaitu 60 orang terdapat pada variabel 2 (orang berseragam putih).

Tabel 2. Tingkat rasa takut anak pada perawatan penambalan gigi berdasarkan jenis kelamin.

\begin{tabular}{ccccc}
\hline \multirow{2}{*}{ Tingkat } & \multicolumn{4}{c}{ Jenis Kelamin } \\
\cline { 2 - 5 } Rasa Takut & \multicolumn{2}{c}{ Laki-Laki } & \multicolumn{2}{c}{ Perempuan } \\
\cline { 2 - 5 } & $\sum$ (orang) & $\mathbf{\%}$ & $\sum$ (orang) & $\mathbf{\%}$ \\
\hline Rendah & 19 & 76 & 20 & 57 \\
Sedang & 6 & 24 & 15 & 43 \\
Tinggi & 0 & 0 & 0 & 0 \\
\hline Total & $\mathbf{2 5}$ & $100 \%$ & $\mathbf{3 5}$ & $100 \%$ \\
\hline
\end{tabular}

Pada tabel 2 dapat dilihat persentase rasa takut anak laki-laki yang memiliki tingkat rasa takut rendah 76\% (19 orang) dan tingkat rasa takut sedang 24\% (6 orang) sedangkan anak yang memiliki tingkat rasa takut tinggi tidak ada. Sementara itu persentase anak perempuan yang memiliki tingkat rasa takut rendah 57\% (20 orang) dan tingkat rasa takut sedang 43\% (15 orang) sedangkan anak yang memiliki tingkat rasa takut tinggi tidak ada.

Tabel 3. Tingkat rasa takut anak pada perawatan penambalan gigi berdasarkan pendidikan orang tua.

\begin{tabular}{lcccc}
\hline \multirow{2}{*}{$\begin{array}{c}\text { Pendidikan Orang Tua } \\
\text { (Ayah) }\end{array}$} & \multicolumn{3}{c}{ Tingkat Rasa Takut } & \multirow{2}{*}{ Total } \\
\cline { 2 - 4 } & Rendah & Sedang & Tinggi & \\
\hline SMP & 0 & 9 & 0 & 9 \\
SMA/SMK/STM & 10 & 12 & 0 & 22 \\
D3 & 2 & 0 & 0 & 2 \\
S1 & 27 & 0 & 0 & 27 \\
\hline Total & $\mathbf{3 9}$ & $\mathbf{2 1}$ & $\mathbf{0}$ & $\mathbf{6 0}$ \\
\hline
\end{tabular}

Jumlah anak dengan tingkat rasa takut sedang pada orang tua pendidikan terakhir SMP adalah 9 orang anak, sedangkan pada tingkat rendah dan tinggi tidak ada. Jumlah anak dengan tingkat rasa takut rendah pada orang tua pendidikan terakhir SMA/SMK/STM adalah 10 orang anak dan pada tingkat sedang 12 orang anak, sedangkan pada tingkat tinggi tidak ada. Jumlah anak dengan tingkat rasa takut rendah pada orang tua pendidikan terakhir D3 adalah 2 orang anak, sedangkan pada tingkat sedang dan tinggi tidak ada. Jumlah anak dengan tingkat rasa takut rendah pada orang tua pendidikan terakhir S1 adalah 27 orang anak, sedangkan pada tingkat sedang dan tinggi tidak ada.

Tabel 4. Tingkat rasa takut anak pada perawatan penambalan gigi berdasarkan pekerjaan orang tua.

\begin{tabular}{lcccc}
\hline \multirow{2}{*}{ Pekerjaan Orang Tua (Ayah) } & \multicolumn{3}{c}{ Tingkat Rasa Takut } & \multirow{2}{*}{ Total } \\
\cline { 2 - 4 } & Rendah & Sedang & Tinggi & \\
\hline Pegawai Negeri & 13 & 2 & 0 & 15 \\
Pegawai Swasta & 6 & 0 & 0 & 6 \\
Pegawai BUMN & 11 & 0 & 0 & 11 \\
Pegawai BUMD & 5 & 0 & 0 & 5 \\
\hline
\end{tabular}




\begin{tabular}{lcccc}
\hline Wiraswasta & 3 & 2 & 0 & 5 \\
TNI/Polisi & 1 & 3 & 0 & 4 \\
Pedagang/Petani/Tukang/Buruh & 0 & 14 & 0 & 14 \\
\hline Total & $\mathbf{3 9}$ & $\mathbf{2 1}$ & $\mathbf{0}$ & $\mathbf{6 0}$ \\
\hline
\end{tabular}

Jumlah anak dengan tingkat rasa takut rendah pada orang tua dengan pekerjaan sebagai pegawai negeri adalah 13 orang sedangkan yang masuk dalam tingkat rasa takut sedang adalah 2 orang dari total keseluruhan 15 orang. Jumlah anak dengan tingkat rasa takut rendah pada orang tua dengan pekerjaan sebagai pegawai swasta adalah total keseluruhan anak yaitu 6 orang. Jumlah anak dengan tingkat rasa takut rendah pada orang tua dengan pekerjaan sebagai pegawai BUMN adalah total keseluruhan anak yaitu 11 orang. Jumlah anak dengan tingkat rasa takut rendah pada orang tua dengan pekerjaan sebagai pegawai BUMD adalah total keseluruhan anak yaitu 5 orang. Jumlah anak dengan tingkat rasa takut rendah pada orang tua dengan pekerjaan sebagai wiraswasta adalah 3 orang sedangkan yang masuk dalam tingkat rasa takut sedang adalah 2 orang dari total keseluruhan 5 orang. Jumlah anak dengan tingkat rasa takut rendah pada orang tua dengan pekerjaan sebagai TNI atau polisi adalah 1 orang sedangkan yang masuk dalam tingkat rasa takut sedang adalah 3 orang dari total keseluruhan 4 orang. Jumlah anak dengan tingkat rasa takut sedang pada orang tua dengan pekerjaan sebagai dagang, petani, tukang, dan buruh adalah total keseluruhan anak yaitu 14 orang.

\section{B. Pembahasan}

Secara keseluruhan sumber rasa takut yang paling ditakuti anak yaitu saat mendengar bunyi mesin bur dokter gigi dan saat bur bersentuhan dengan gigi. Hasil ini sesuai dengan literatur yang menyatakan prosedur invasif seperti yang berhubungan dengan bur dokter gigi dapat menimbulkan rasa sakit sedangkan rasa sakit merupakan pencetus dari rasa takut pada perawatan gigi dan mulut khususnya pada perawatan penambalan gigi. Alasan ini didukung dengan pendapat yang menyatakan bahwa rasa takut yang tinggi secara signifikan terkait dengan prosedur dental yang invasif seperti yang berhubungan dengan bur gigi. Hal ini diperjelas oleh Kleinknecht dan Lenz yang menyatakan bahwa perawatan invasif tersebut erat kaitannya dengan darah dan perasaan takut akan luka pada tubuh yang tipikal muncul pada anak-anak. Selain itu penelitian Locker, Lindell, Dempster, dan Shapiro menunjukkan bahwa $74,8 \%$ pasien dengan pengalaman dental yang menyakitkan erat kaitannya dengan rasa takut dan tentunya prosedur yang berkaitan dengan bur gigi merupakan hal yang menyakitkan.

Tingkat rasa takut anak berdasarkan pendidikan orang tua dalam hal ini ayah menunjukkan bahwa semakin tinggi jenjang pendidikan orang tua tingkat rasa takut anak semakin rendah. Hal ini sesuai dengan studi yang dilakukan oleh Kamran dan Qiam dimana tingkat pendidikan orang tua berpengaruh secara signifikan terhadap tingkah laku anak pada perawatan gigi dan mulut khususnya perawatan penambalan gigi. Pada penelitian ini tingkat pendidikan menentukan penilaian orang tua terhadap perawatan penambalan gigi anak. Orang tua dengan pendidikan terakhir yang lebih tinggi menunjukkan perhatian yang lebih terhadap kesehatan gigi dan mulut anak, sehingga intensitas kunjungan ke dokter gigi baik itu untuk pemeriksaan rutin ataupun perawatan lebih besar dari orang tua dengan tingkat pendidikan yang lebih rendah.

Tabel 4 menunjukkan bahwa pekerjaan orang tua dalam hal ini ayah berperan penting pada tingkat rasa takut anak terhadap perawatan penambalan gigi. Jenis pekerjaan orang tua akan menentukan tingkat pendapatan yang menentukan status sosial-ekonomi keluarga. Pada penelitian ini pekerjaan orang tua sebagai pegawai negeri, swasta, pegawai BUMN, pegawai BUMD, dan 
wiraswasta menunjukkan bahwa tingkat rasa takut anak adalah rendah, sedangkan pekerjaan orang tua sebagai TNI atau polisi, pedagang, petani, buruh maupun tukang menunjukkan bahwa tingkat rasa takut anak pada perawatan penambalan gigi adalah sedang. Hal ini sesuai dengan pendapat yang dikemukakan oleh Spencer dan Stewart bahwa secara umum orang dengan tingkat sosial ekonomi rendah mempunyai tingkat rasa takut yang lebih tinggi. Dalam studinya Moore menemukan bahwa pendapatan yang rendah adalah faktor resiko tingkat rasa takut sedang dan tidak secara signifikan berhubungan dengan tingkat rasa takut tinggi. Latar belakang pekerjaan orang tua serta status sosial ekonomi juga memengaruhi frekuensi kunjungan anak ke dokter gigi. Orang tua dengan tingkat ekonomi yang tinggi menunjukkan perhatian yang lebih terhadap kesehatan gigi dan mulut anak. Hal ini ditunjukkan dengan kepedulian orang tua yang membawa anak berkunjung ke dokter gigi secara rutin baik untuk tindakan restoratif ataupun kuratif. Sebaliknya pada orang tua dengan tingkat ekonomi yang lebih rendah cenderung berkunjung ke dokter gigi jika kerusakan yang dialami sudah lebih parah sehingga sangat mengganggu aktivitas anak.

\section{SIMPULAN}

Secara umum tingkat rasa takut anak pada perawatan penambalan gigi usia 10-11 tahun di SD GMIM IV Tomohon masuk dalam kategori tingkat rasa takut rendah. Sebanyak 39 orang anak memiliki tingkat rasa takut rendah dan 21 orang anak termasuk dalam kategori tingkat rasa takut sedang, sedangkan yang termasuk dalam tingkat rasa takut tinggi tidak ada. Sumber rasa takut yang paling menakutkan pada pasien anak adalah saat mendengar bunyi mesin bur dokter gigi dan saat dokter gigi mengebur atau bur bersentuhan dengan gigi.

\section{DAFTAR PUSTAKA}

1. Manurung, YRL. Rasa Takut Terhadap Perawatan Gigi (Dental Phobia) dan Penanggulannya. Tesis Pascasarjana Universitas Sumatera Utara. Universitas Sumatera Utara Medan. 2008. Hal 12-19.

2. Cameron A, Widmer R, Drummond B, et al. Child management. In: Cameron AC, Widmer RP. Handbook of Pediatric Dentistry 2nd ed. Edinburg: Mosby; 2010:1-26.

3. Salem K, Kousha M, Anissian A, et al. Dental Fear and Concominant Factors in 3-6 Year-old Children. J Dent Res Dent Clin Dent Prospects. 2012 Spring; 6(2): 70-74.

4. Wright GZ, Starkey PE, Gardner DE. Child Management in Dentistry 2nd. Bristol:Wright, 1987:28-41.

5. Suprabha BS, Rao A, Choudhary S, et al. Child dental fear and behaviour: The role of environmental factors in a hospital cohort. J Indian Soc Pedod Prev Dent. 2011;29(2):95-101.

6. Roberts JF, Curzon MEJ, Koch G, et al. Review: Behaviour Management Techniques in Paediatric Dentistry. Eur Arch Paediatr Dent. 2010 Aug;11(4):166-74.

7. Wright GZ. Nonpharmacologic management of children's behaviors. In: McDonald RE, Avery DR, Dean JA, eds. Dentistry for the child and adolescent 8th ed. Indiana: Mosby;2004:35-49.

8. Brauer JC, Dameritt WW, Higley LB, et al. Dentistry for children 4th ed. New York: McGrawHill Book Company, 1959: 24-37.

9. Armfield, JM. How do we measure dental fear and what are we measuring anyway?. Oral Health Prev Dent. 2010;8(2):107-15. 